\title{
COMPUTATIONAL METHOD FOR PROTEIN STRUCTURE PREDICTION AND DRUG DESIGN AGAINST COVID -19
}

\author{
Deshmukh Sanket Surendra \\ Department of Agrochemicals and Pest management \\ Shivaji university \\ Kolhapur India
}

\begin{abstract}
In modern drug discovery, a detailed understanding of interactions between small chemical compounds and biomolecular macromolecules (e.g. medicinal agents and their targets) is of crucial importance.1 The search for drug-like compounds that selectively bind to a molecular target and interfere with its receptor function or enzymatic activity demands a multi- and interdisciplinary approach. Hereby, computer modeling serves as an important tool to understand the relevant ligand-receptor or ligand-enzyme interactions. Nowadays, it is difficult to imagine drug discovery without computation. Almost all critical function in cell rely on specific protein. Understanding these is therefore crucial in investigation of biological system Drug design and drug discovery are critical importance in human health care, Computational approaches have become a major part of structure based drug design. In this review computational method for prediction of protein structure are described and their use toward drug design is discovered.
\end{abstract}

\section{INTRODUCTION}

Coronaviruses are a family of viruses that can cause illnesses such as the common cold, severe acute respiratory syndrome (SARS) and Middle East respiratory syndrome (MERS). In 2019, a new coronavirus was identified as the cause of a disease outbreak that originated in China.

The virus is now known as the severe acute respiratory syndrome coronavirus 2 (SARS-CoV-2). The disease it causes is called coronavirus disease 2019 (COVID-19). In

March 2020, the World Health Organization (WHO) declared the COVID-19 outbreak a pandemic Coronaviruses
(CoVs) (order Nidovirales, family Coronaviridae, subfamily are enveloped viruses with a positive sense, single-stranded RNA genome. With genome sizes ranging from 26 to 32 kilobases $(\mathrm{kb})$ lin length, CoVs have the largest genomes for RNA viruses. Based on genetic and antigenic criteria, CoVs have been organised into three groups: $\alpha-\mathrm{CoVs}, \beta-\mathrm{CoVs}$, and $\gamma$-CoVs. The corona virus family is a positive-stranded RNA virus, which mainly causes respiratory and central nervous system disease in humans and animals].

There is an urgent need for the development of anti-viral drugs and vaccines against the 2019-nCov virus due to the high mortality rate of patients. The aim of the study is to use to computational approach to design both anti-viral drug and vaccine candidates. The spike protein in the novel coronavirus sequence is used to design both anti-viral drug and vaccine candidates.

\section{MATERIAL \& METHOD}

NCBI protein database - 6M03-A PDB ID For further analysis the sequence was downloaded as the FASTA sequence.

Homology Modeling using Phyre software

Ligand predicted by Galxey tool, ProBis

\section{EXPERIMENT AND RESULT}

- analysis show how virus is evolutionary history with bats coronavirus

- Homology modeling using phyre indicate identity with $3 \mathrm{C}$ like proteinase

- $\quad$ Ligand predicted by Galxy web - D3F, RFM

- Using probis predicted- Small molecule ligand - 4 Methylbenzene diaminozinc. 
International Journal of Engineering Applied Sciences and Technology, 2020

Vol. 5, Issue 3, ISSN No. 2455-2143, Pages 630-636

Published Online July 2020 in IJEAST (http://www.ijeast.com)

BLAST SEQUENCE ANALYSIS

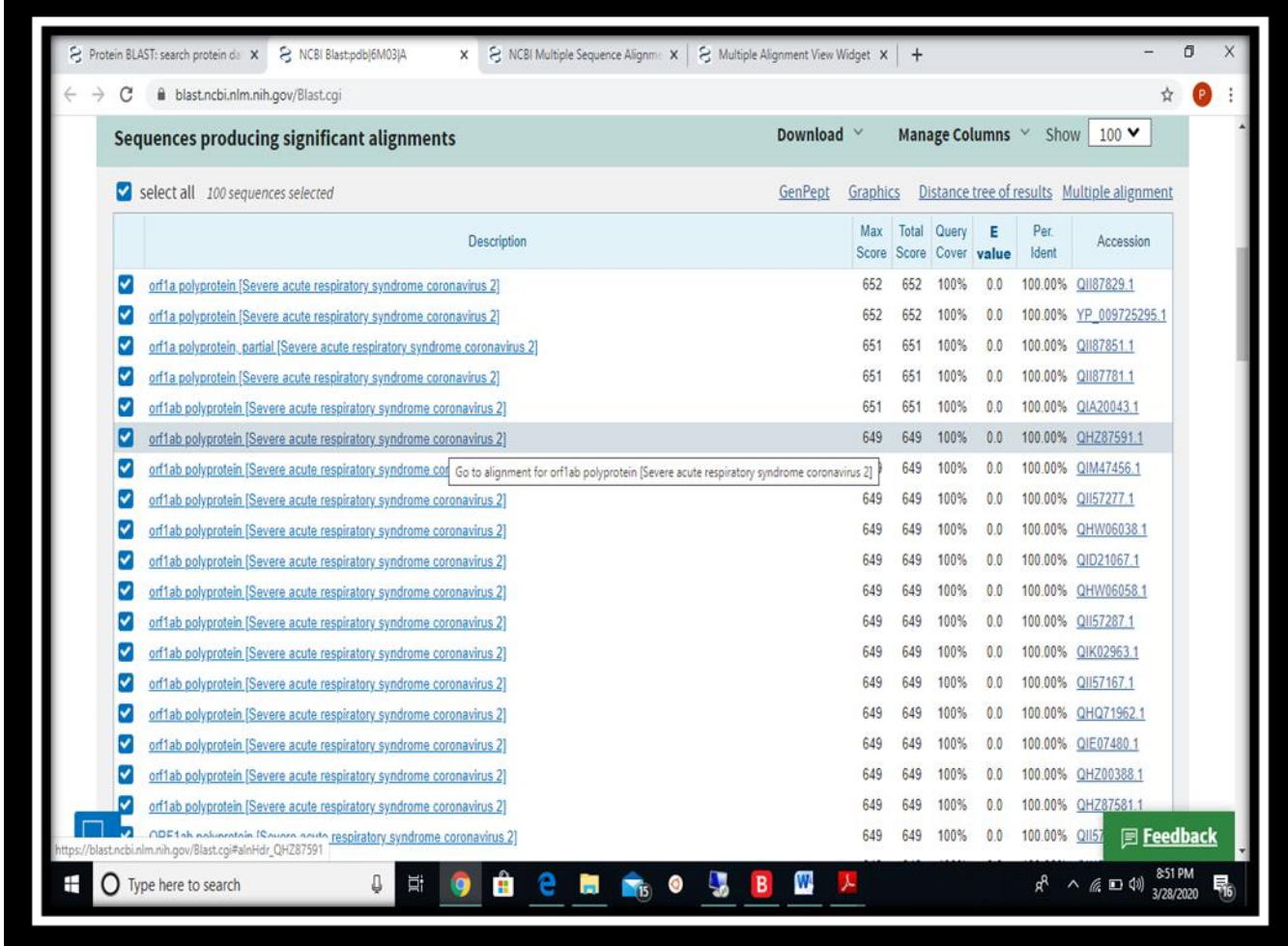

Fig 1 - blast sequence alignments

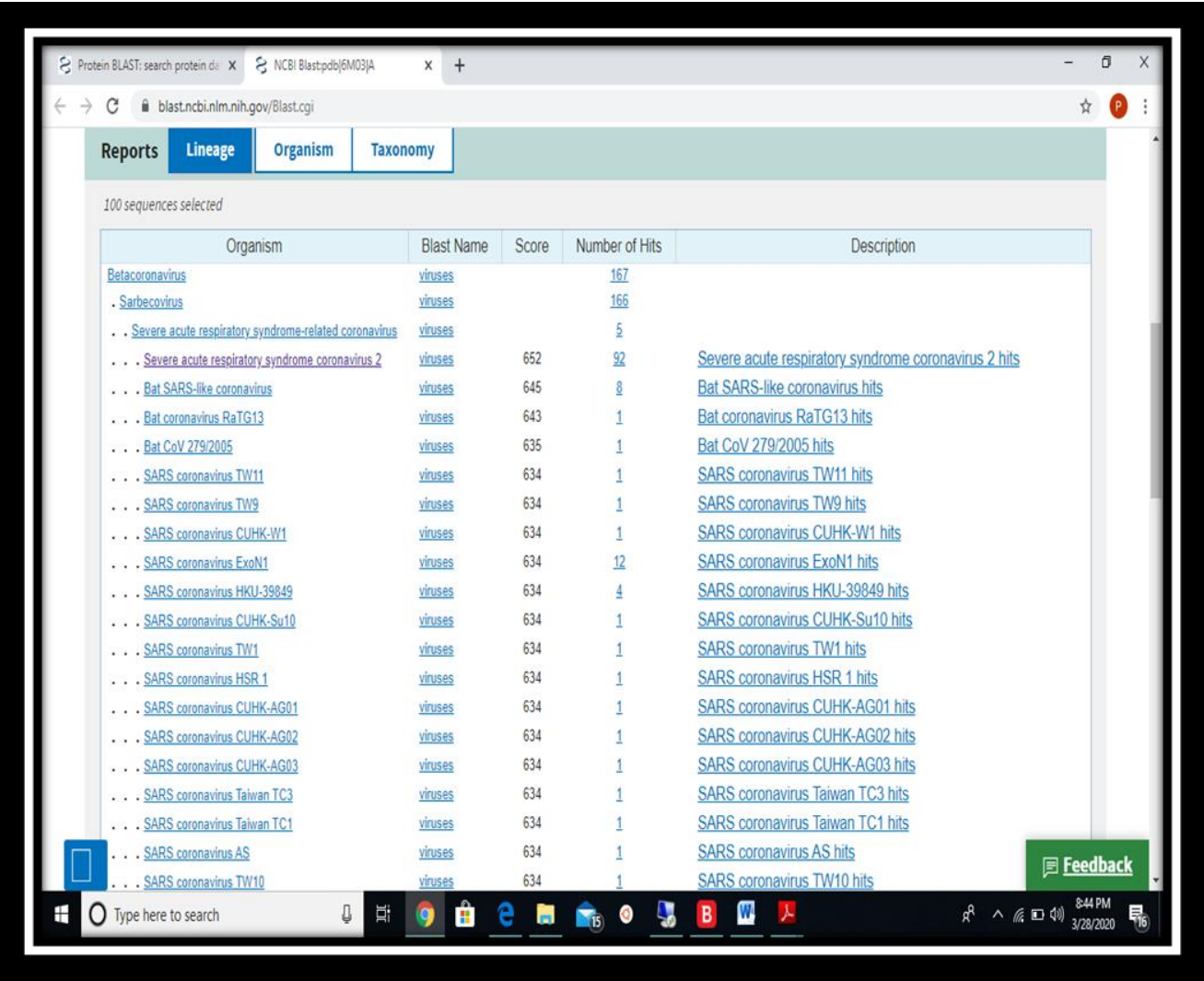

Fig 2- top sequence similarities 
International Journal of Engineering Applied Sciences and Technology, 2020 Vol. 5, Issue 3, ISSN No. 2455-2143, Pages 630-636

Published Online July 2020 in IJEAST (http://www.ijeast.com)

HOMOLOGY MODELING USING PHYRE

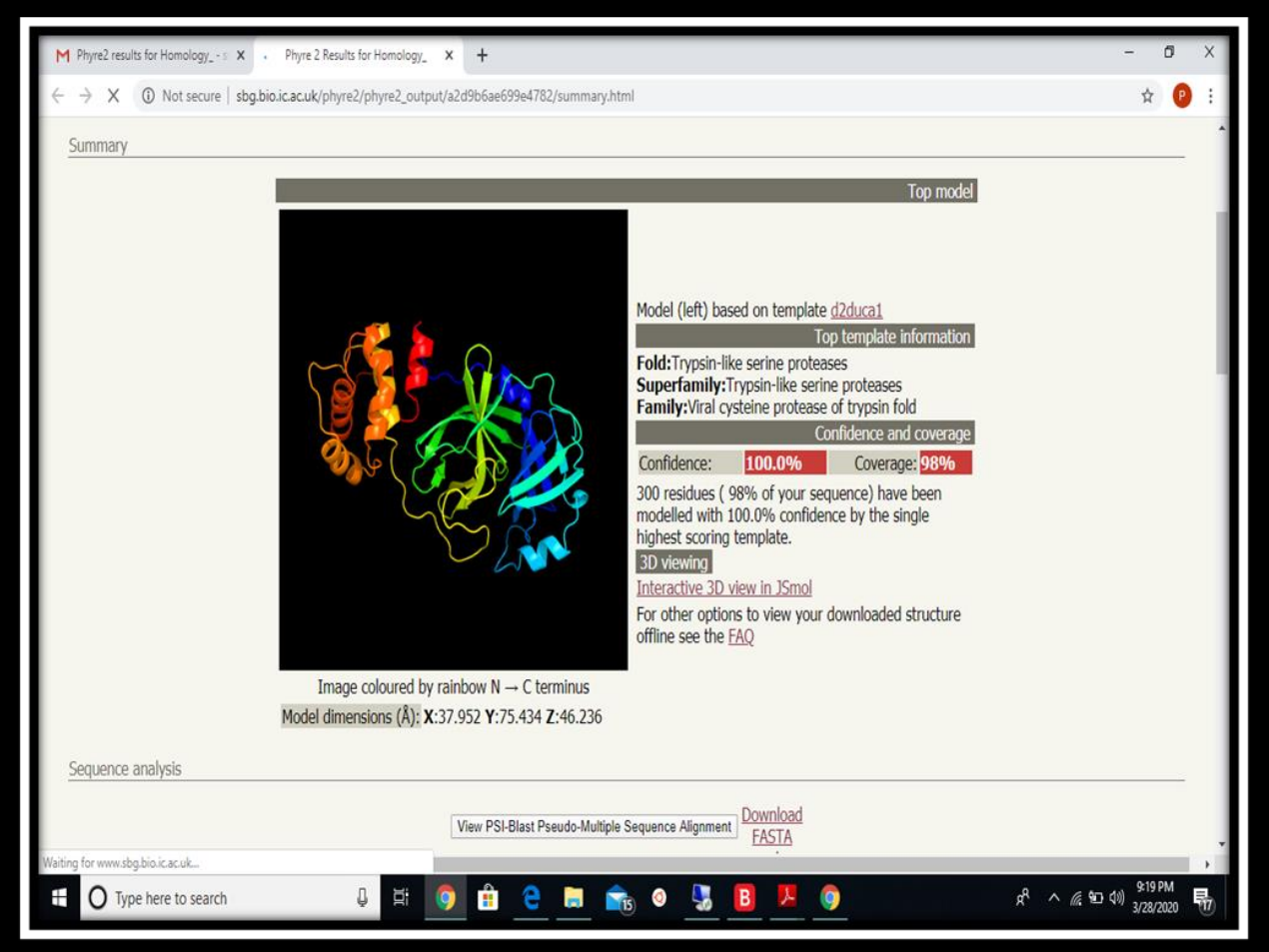

Fig 3 - Homology modeling structure

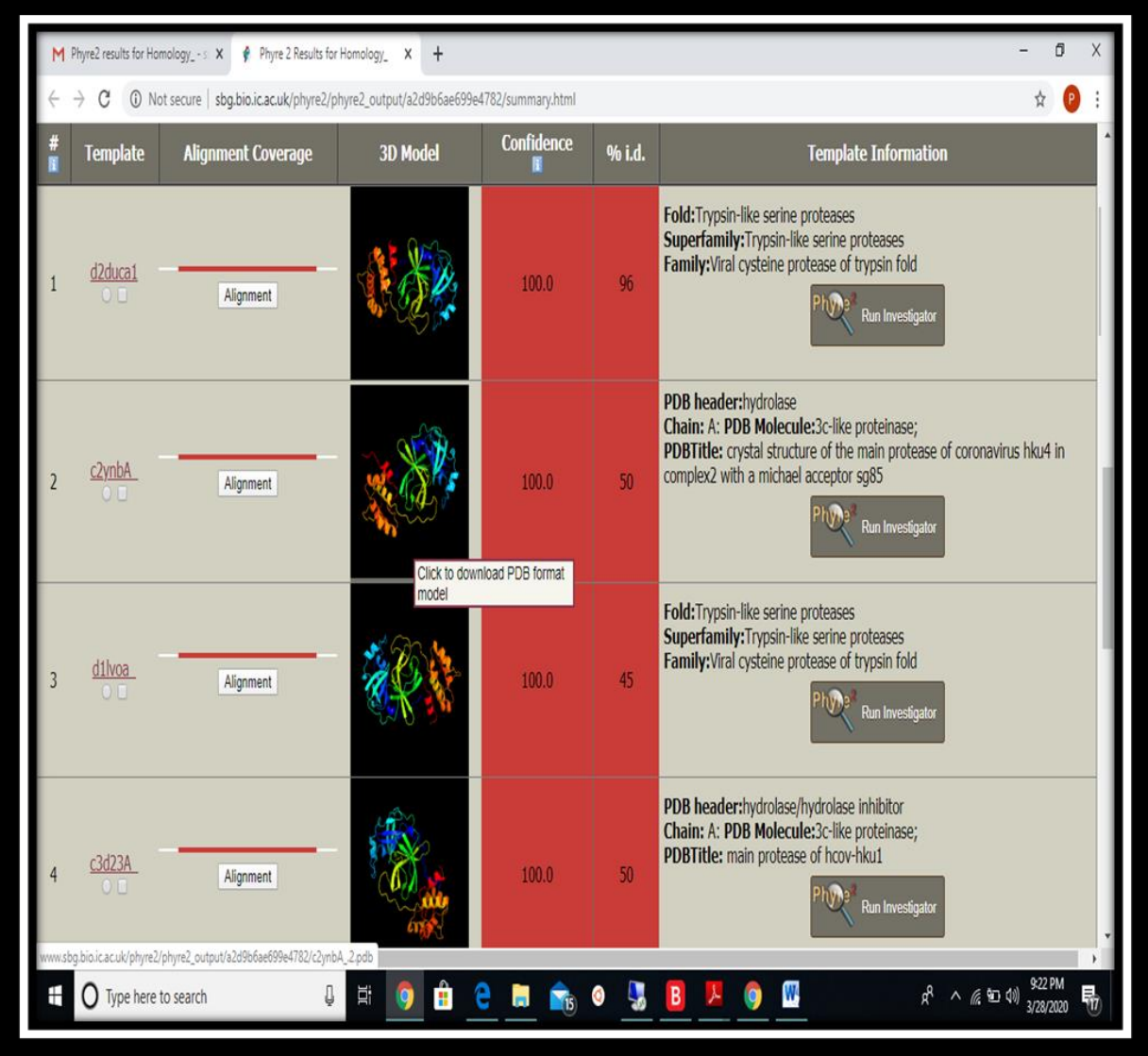

Fig 4 -top rated alignments 
International Journal of Engineering Applied Sciences and Technology, 2020 Vol. 5, Issue 3, ISSN No. 2455-2143, Pages 630-636

Published Online July 2020 in IJEAST (http://www.ijeast.com)

LIGAND BINDING USING GALAXY

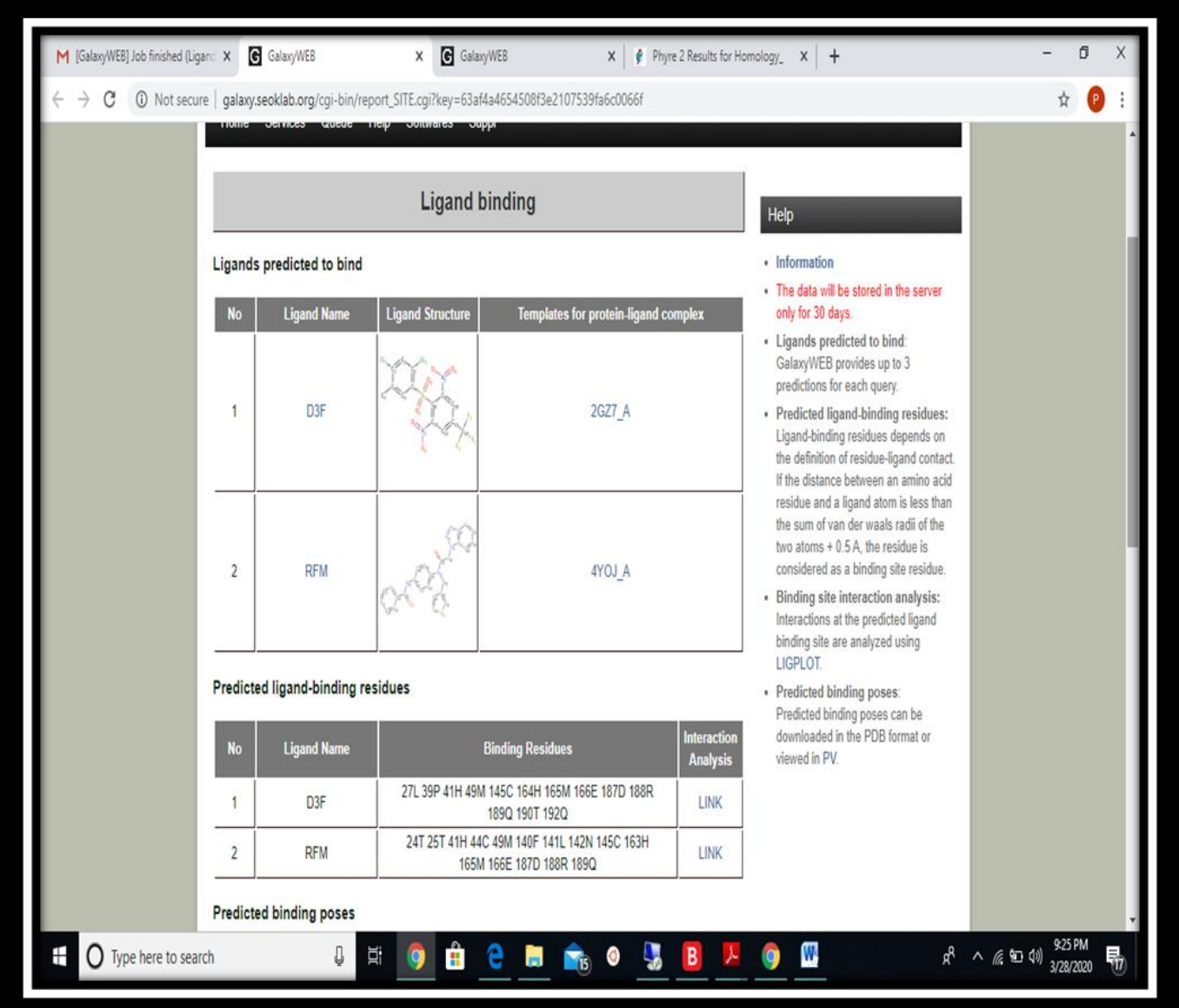

Fig 5-ligand predicted by galxy web

PREDICTED BINDING POSES

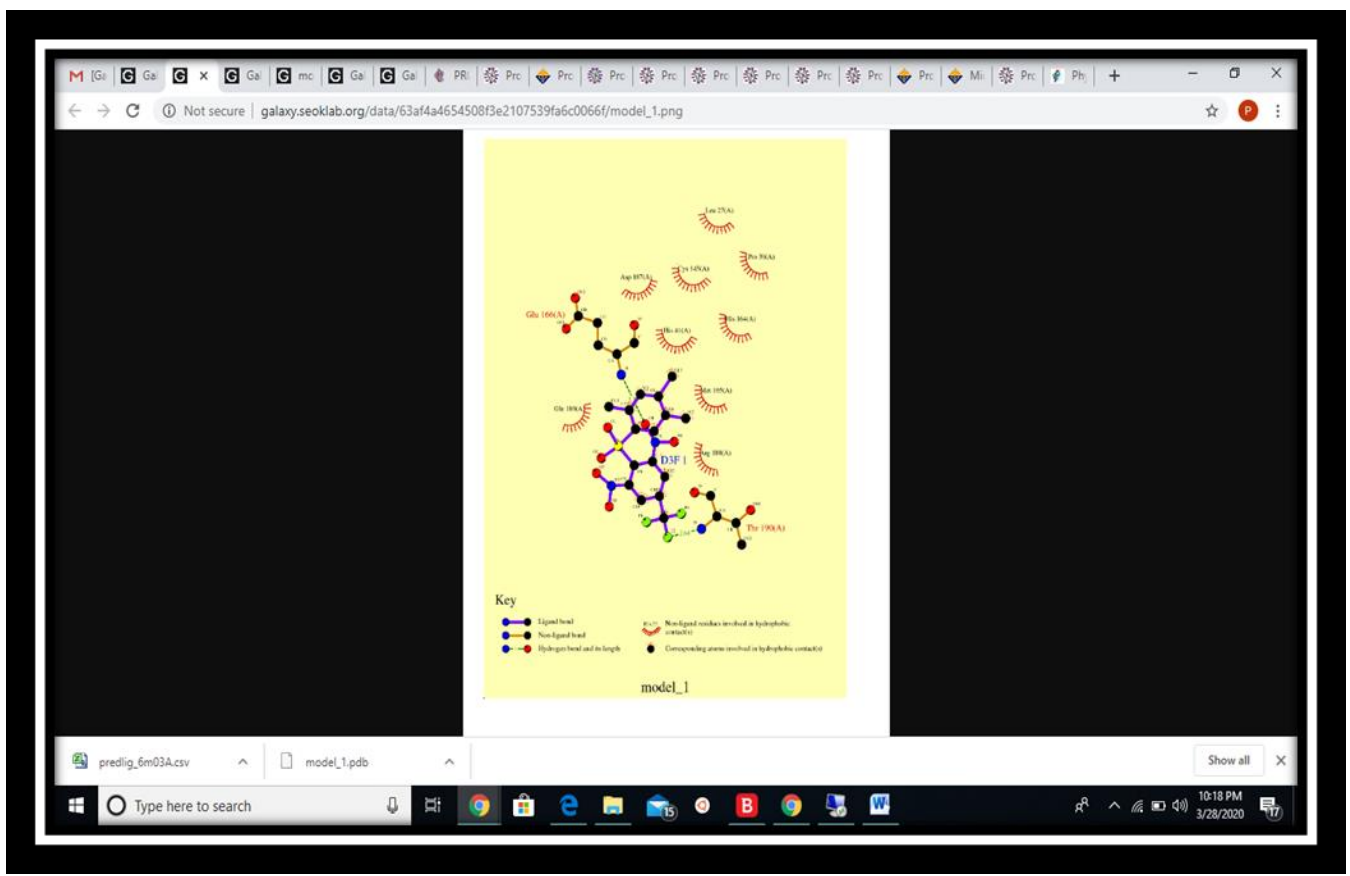

Fig 6 -site predicted by galaxy web model 1 
International Journal of Engineering Applied Sciences and Technology, 2020

Vol. 5, Issue 3, ISSN No. 2455-2143, Pages 630-636

Published Online July 2020 in IJEAST (http://www.ijeast.com)

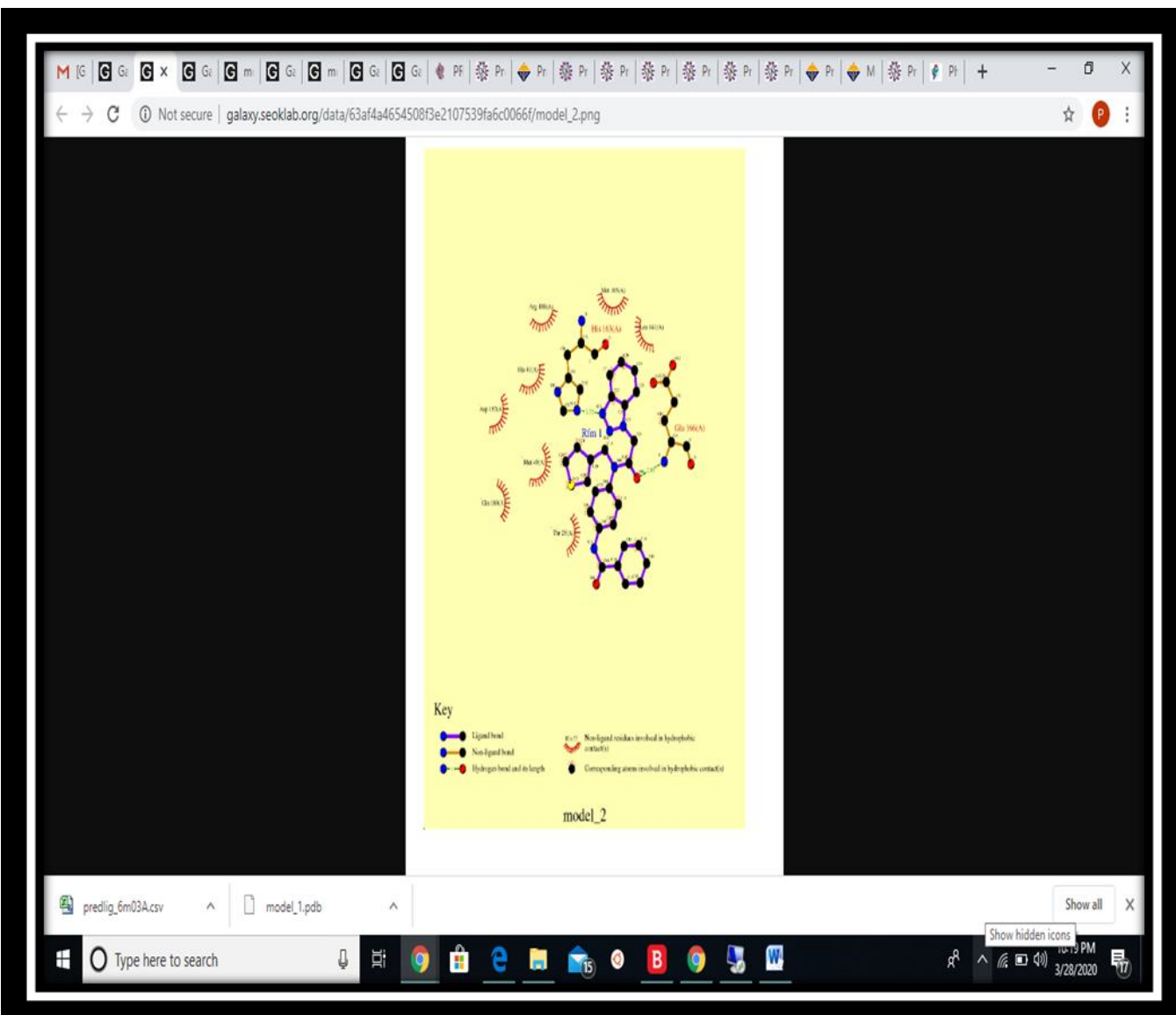

Fig 7 -site predicted model 2

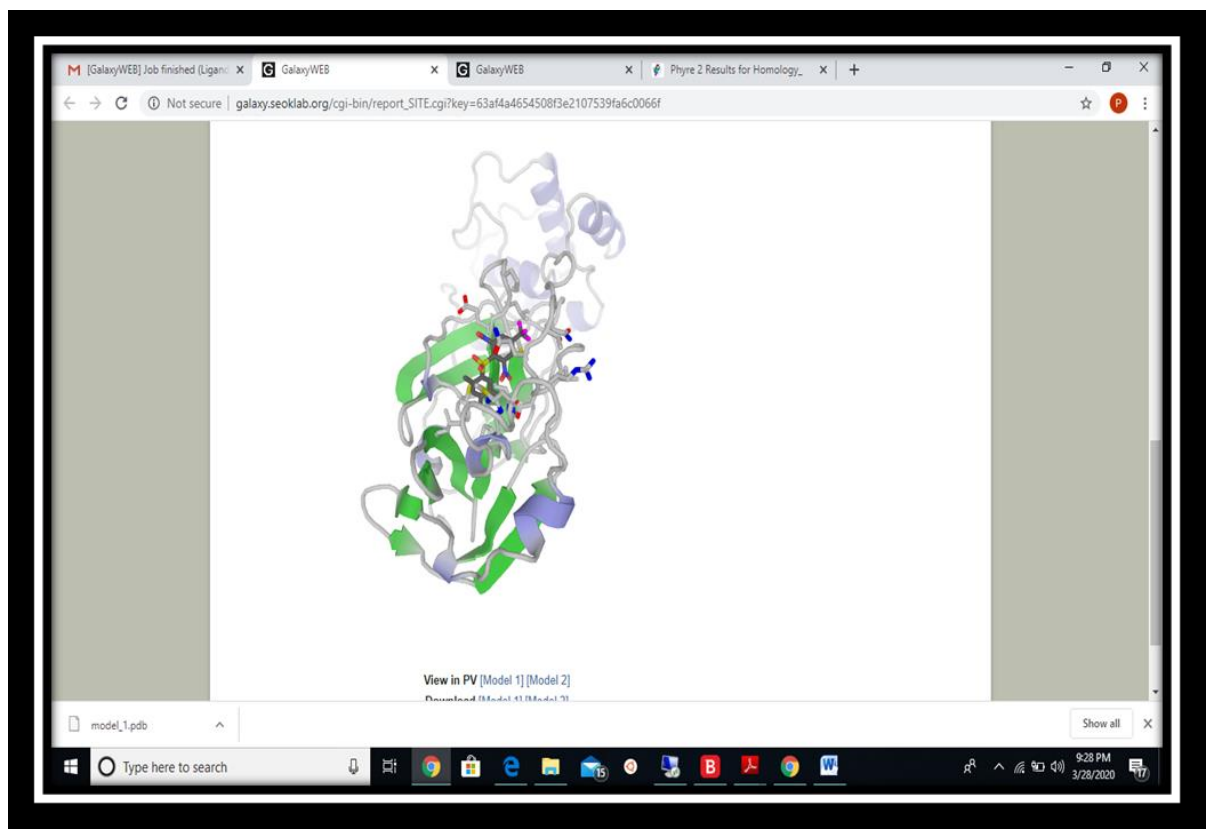

Fig 8 -predicted model

proBis web servers into one functional unit that enables prediction of protein-ligand complexes and allows for their geometry optimization and interaction energy calculation. The ProBiS web server predicts ligands (small compounds, proteins, nucleic acids, and single-atom ligands) that may bind to a query protein 


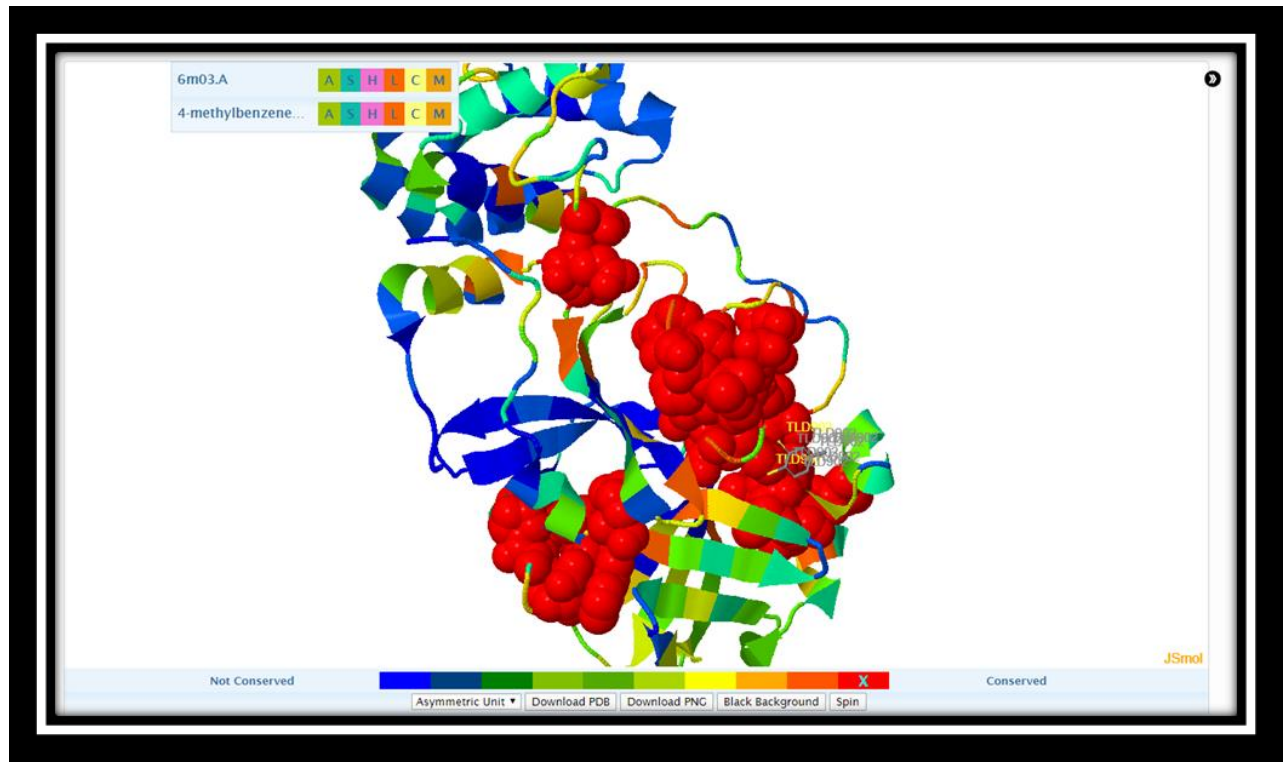

Fig 9- showing 4 methylbenzene binding geometry

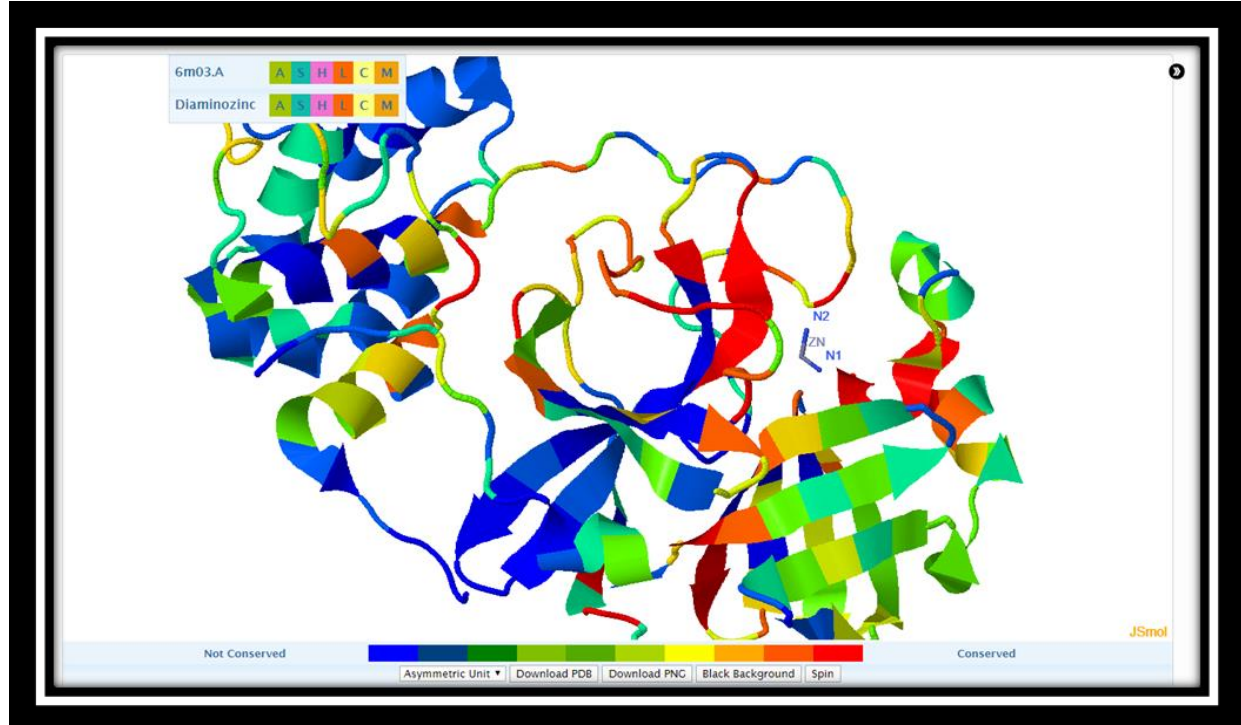

Fig 10 - showing diaminozinc binding geometry

\section{CONCLUSION}

Due to the scarcity of experimental and clinical data, as well as the urgency to understand the infectivity of the deadly coronaviruses. computational analyses to study the 2019$\mathrm{nCoV}$ virus in terms of protein structures, functions, phylogeny, and interactions at both molecular and organismal levels. In the present study, both drug and vaccine design was applied to identify drug and vaccine this approach will be cost effective and can save time in the design of drugs.

\section{ACKNOWLEDGEMENTS}

I thanks to Shri. N.V. Ingole Assistant Professor. AGRIBIOTECHNOLY COLLEGE AMRAVATI for lending her expertise and encourage to me. Deepest gratitutude to Dr,P,D Shirgave Coordinater department of Agrochemicals and Pest Management, Devchand College, Arjunnagar whose sincerity and encouragement I will never forget

\section{REFERENCS}

1. Snijder, E.J.; Bredenbeek, P.J.; Dobbe, J.C.; Thiel, V.; Ziebuhr, J.; Poon, L.L.; Guan, Y.; Rozanov, M.; Spaan, W.J.; Gorbalenya, A.E. 2003 Unique and conserved features of genome and proteome ofbSARS-coronavirus, an early split-off from the coronavirus group 2 lineage. J. Mol. Biol.331,9911004.

2. Woo, P.C.; Lau, S.K.; Lam, C.S.; Lai, K.K.; Huang, Y.; Lee, P.; Luk, G.S.; Dyrting, K.C.; Chan,K.H.; Yuen, K.Y. 2009 Comparative analysis of complete genome sequences of three avian coronaviruses reveals a novel group $3 \mathrm{c}$ coronavirus. J. Virol. 83, 908-917. 
3 Lu CW, Liu XF, Jia ZF. 2019-nCoV 2000 transmission through the ocular surface must not be ignored. Lancet [PMID: 32035510 DOI: 10.1016/S0140-6736(20)30313-5]

$4 \mathrm{Lu} \mathrm{H}$. Drug treatment options for the 2019-new coronavirus (2019-nCoV). Biosci Trends 2020 [PMID:31996494 DOI: 10.5582/bst.2020.01020]

5 Lu H, Stratton CW, Tang YW 2000. Outbreak of pneumonia of unknown etiology in Wuhan, China: The mystery and the miracle. J Med Virol 2020 [PMID: 31950516 DOI: 10.1002/jmv.25678]

6 Wang W, Tang J, Wei F. Updated understanding of the outbreak of 2019 novel coronavirus (2019-nCoV) in Wuhan, China. J Med Virol 2020 [PMID: 31994742 DOI: 10.1002/jmv.25689]

7 Wang Z, Chen X, Lu Y, Chen F, Zhang W. 2000 Clinical characteristics and therapeutic procedure for four medicine

treatment. Biosci Trends 2020 [PMID: 32037389 DOI: 10.5582/bst.2020.01030]

8. Cheng, F. 2000 In silico oncology drug repositioning and polypharmacology. Methods Mol. Biol. 1878, 243-261

9. Cheng, F., Hong, H., Yang, S. \& Wei, Y. 2017 Individualized network-based drug repositioning infrastructure for precision oncology in the panomics era. Brief Bioinformatics 18, 682-697

10 Huang, H.J. et al. 2010 Current developments of computeraided drug design. , Journal of the Taiwan Institute of Chemical Engineers.

11 Kapetanovic, I.M. (2008) Computer-aided drug discovery and development (CADDD): In silico-chemico-biological approach. Chemico-Biological Interactions DOI: 10.1016/j.cbi.2006.12.00612 Drie, J.H. (2007)

12 Veselovsky, A. V. and Ivanov, A.S.2003 Strategy of computer-aided drug design., Current Drug Targets Infectious Disorders.

13 janez koncc. Benjamin T MILLER ,Tanja stular 2015 Probis web interface for predication and optimization of ligand in protein binding site.

14 Daniel blankenberg Gregory von kuster ,Nathaniel coraor 010 Jan;Chapter 19:Unit 19.10.1-21. doi: 10.1002/0471142727.mb1910s89. - Galaxy a web based tool for genome analysis.
15 . Lazarczyk M, Favre M (2008) Role of Zn2+ ions in hostvirus interactions. J Virol 82: 11486-11494.

16. Frederickson CJ, Koh JY, Bush AI (2005) Neurobiology of zinc in health and disease. Nat Rev Neurosci 6: 449-462.

17. Alirezaei M, Nairn AC, Glowinski J, Premont J, Marin P (1999) Zinc inhibits protein synthesis in neurons: potential rol of phosphorylation of translation initiation factor-2a. J Biol Chem 274: 32433-32438.

18. Uchide N, Ohyama K, Bessho T, Yuan B, Yamakawa T (2002) Effect of antioxidants on apoptosis induced by influenza virus infection: inhibition of viral gene replication and transcription with pyrrolidine dithiocarbamate. Antiviral Res 56: 207-217.

19 Suara RO, Crowe JEJ (2004) Effect of zinc salts on respiratory syncytial virus replication. Antimicrob Agents Chemother 48: 783-790.

20 Aartjan J. W. te Velthuis,Sjoerd H. E. van den Worm,Amy C. Sims, Ralph S. Baric,Eric J. Snijder ,Martijn J. van Hemert Published: November 2010https://doi.org/10.1371/journal.ppat.1001176

21 Knox C, Law V, Jewison T, Liu P, Ly S, Frolkis A, Pon A, Banco K, Mak C, Neveu V, Djoumbou Y, Eisner R, Guo AC, Wishart DS. Nucleic Acids Res. 2011 Jan; 39 (Database issue):D1035-41. | PMID:21059682DrugBank 3.0: a comprehensive resource for 'omics' research on drugs.. Nucleic Acids Res. 2011 Jan; 39 (Database issue):D1035-41. | PMID:21059682

22 : DrugBank 3.0: a comprehensive resource for 'omics' research on drugs. Knox C, Law V, Jewison T, Liu P, Ly S, Frolkis A, Pon A, Banco K, Mak C, Neveu V, Djoumbou Y, Eisner R, Guo AC, Wishart DS. Nucleic Acids Res. 2011 Jan; 39 (Database issue):D1035-41. | PMID:2105968 Enhanced morphology of L-histidinium 4-methylbenzene sulfonate via recrystallization and study on its physio-chemical,

23 lawrence A Kelley, Stefans Mezulis, Christopher M Yates, Mark N Wass \& Michael J E Sternberg 201 The Phyre2 web portal for protein modeling, prediction and analysis . Nature Protocols volume 10, pages845-858(2015\}

24 Konc, J., Miller, B. T., Stular, T., Lesnik, S., Woodcock, H. L., Brooks, B. R., and Janezic, D. ProBiS-CHARMMing:2015 Web Interface for Prediction and Optimization of Ligands in Protein Binding Sites. J. Chem. Inf. Model., 55, 2308-2314. 